\title{
NEMZETKÖZI PIACSZEGMENTÁCIÓ A TEJTERMÉKEK PIACÁN
}

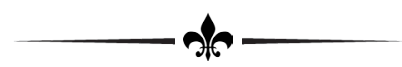

INTERNATIONAL MARKET SEGMENTATION IN DAIRY MARKET

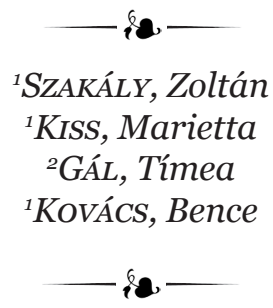

${ }^{1}$ Debreceni Egyetem, Gazdaságtudományi Kar, Marketing és Kereskedelem Intézet (University of Debrecen, Faculty of Economics and Business, Institute of Marketing and Commerce) H-4032 Debrecen, Böszörményi út 138 . e-mail: szakaly.zoltan@econ.unideb.hu

${ }^{2}$ Debreceni Egyetem, Gazdaságtudományi Kar, Gazdálkodástudományi Intézet, Vállalkozásfejlesztés nem önálló Tanszék (University of Debrecen, Faculty of Economics and Business, Institute of Applied Economics, Department of Entrepreneurship Development) H-4032 Debrecen, Böszörményi út 138.

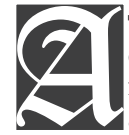

The basis and primary condition of the production level worldwide is the stability of domestic consumption, therefore the size of milk production is determined by the domestic milk consumption apart from smaller or greater exceptions. The aim of this research is to accomplish an international market segmentation based on the volume of milk product consumption. Segment forming variables were the three-year average per capita consumption volumes of liquid milk, cheese (including cottage cheese), and butter in the particular national economies. 46 national economies and the European Union (EU28) were included in the research. After completing the segmentation, our further aim was to characterize the formed segments by the following macro factors: gross domestic product (GDP) per capita, gross national income (GNI) per capita, life expectancy at birth, crude mortality rate, unemployment rate, and consumption expenditures of households as a percentage of gross domestic product. Based on our results, three clusters were identified that significantly differ from each other. The first cluster includes those countries where liquid milk, cheese, and butter consumption per capita are low. The second cluster contains those nations in which per capita consumption can be seen as medium level, Hungary is in this group. In the third cluster we can find countries with high per capita consumption compared to the sample. The formed segments show significant differences according to both GDP and GNI. In the case of segments with higher milk product consumption the means of GDP and GNI are significantly higher on purchasing power parity. In the countries where a higher proportion of gross domestic product is consumed the volume of milk product consumption is lower, while in those countries where a lower proportion of GDP is consumed, the per capita volume of milk product consumption is higher. We found a significant difference among the segments according to the life expectancy, too; life expectancy increases in line with the increase in per capita milk, cheese, and butter consumption. In case of the unemployment rate, we could not find any significant differences among the segments. To sum up, we can conclude that consumption of the examined product categories can be seen as medium in Hungary, i.e. our country belongs to the second segment. Beside Hungary, we can find seven further post-communist countries in this segment that shows the cultural similarity of the region. An important strategic task for Hungary is to increase milk product consumption by the means of communal marketing tools. The consumption of milk products can reach a stable growth path via an appropriate positioning and conscious communications. To reach this goal, the image of the category has to be put in order and healthiness and nutritional advantages of milk products have to be highlighted, then consumer misbeliefs have to be corrected. 


\section{BEVEZETÉS - INTRODUCTION}

Az 1980-as évek kezdetétől a világ táplálkozástudományi kutatásainak homlokterében a Földön fellelhető élelmiszerek bioaktív anyagainak szinte leltárszerű feltérképezése állt, amire azután a funkcionális élelmiszerek egész sorának kifejlesztése épült. A vázolt világkutatás filozófiáját az emberi egészség megóvása, egy jobb életminőség biztosítása adta és adja. Az elvégzett kutatások első helyen említendő összegzett eredménye az, hogy az élelmiszerek közül a tej és termékei a leggazdagabbak bioaktívumokban, és e megállapítás - örömteli módon - vonatkozik valamennyi fő tejalkotóra, így a tejzsírra, tejfehérjékre, tejcukorra, tejsókra és a tejvitaminokra egyaránt (SZAKÁLY, 1999).

A tejtermékek tápanyag-összetételükben a többi élelmiszer fölé emelkednek. E tény rögzítése azért fontos, mert a fejlettebb országokban, de már a fejlődőkben is a lakosság egyre több olyan élelmiszert fogyaszt, amelyek energiasűrüsége magas, tápanyagsűrűsége viszont alacsony (pl. cukrozott üdítőitalok). Természetesen az ideális az lenne, ha olyan élelmiszereket fogyasztanánk, amelyek tápanyagokban gazdagok és energiában szegények. Ennek a kritériumnak kimagaslóan megfelelnek a különböző tejtermékek.

A világon mindenütt a termelés színvonalának alapja, elsődleges feltétele a belföldi fogyasztás stabilitása. Még inkább így van ez a tejgazdaságban, amit az is bizonyít, hogy a tejtermékek világkereskedelme nem éri el az összes termelt tej 10\%-át. A nemzetek tejtermelésének nagyságát tehát - kisebb-nagyobb kivételektől eltekintve - a hazai tejtermékfogyasztás határozza meg (SZAKÁLY, 1999).

A hazai tejtermék-fogyasztási cél megfogalmazásánál az egyik kiindulási támpont, hogy a gyakran „magyar néma járvány”-ként minősített csontritkulás (oszteoporózis) mögött álló 1:2 Ca:P aránynak az 1:1 ideálisra való kiegyenlítéséhez, mint népegészségügyi alapelváráshoz mintegy 260-270 kg/fó/év tejben kifejezett összes tejtermékfogyasztásra lenne szükség. Ezen ideális cél elérésének realitása a közeli jövőben igen csekély: nemcsak amiatt, hogy ez a jelenlegi 150-165 kg/fó éves összes tejter- mékfogyasztásnak közel a duplája, hanem amiatt is, hogy ennek nincsenek meg a gyökerei a sajátságos magyar étrendben, másfelől az ilyen hatalmas növekmény a lehetségesnél nagyobb és dinamikusabb vásárlóerő-növekedést feltételezne (SZAKÁLY, 2013).

A belátható jövőben ezért valósabb cél lehet a $200 \mathrm{~kg} /$ fö/év összes tejtermékfogyasztás. Miután 1987-ben már ezen az értéken voltunk, ezért ez a fogyasztási szint a közeli múltban már megvalósult állapot újbóli elérését jelentené. Ez a reálisan elérhető fogyasztási szint minimálisan kielégíti azokat a néptáplálkozási, illetve népegészségügyi elvárásokat is, amelyek a tejtermék-összetevők egészségvédő funkcióiból származnak (SZAKÁLY, 1999; SZAKÁLY, 2017).

A tudatos és piacorientált vállalati múködés egyik kulcseleme a célpiaci marketinggondolkodás, aminek lényege, hogy fókuszálja a vállalati döntéshozók, a marketingesek tekintetét, továbbá a vállalati erőfeszítéseket az eredményesebb, hatékonyabb piaci beavatkozások és a vállalati siker érdekében (JÓZSA, 2014). Általánosan elmondható, hogy minden vállalat számára a piacválasztás egy stratégiai kérdés, így van ez a nemzetközi piacválasztás során is. Amikor a külpiacra lépésről kell dönteni, a fogyasztói igények felmérését, vizsgálatát rendszerint megelőzi az országszintű szegmentáció. Azaz a vállalat a potenciális országokat (célpiacokat) homogén csoportokra bontja és e csoportokat releváns tényezók alapján elemzi. A csoportosítás történhet általános piaci jellemzők (földrajzi, demográfiai, gazdasági, piaci, politikai és kulturális) vagy specifikus termékpiaci jellemzők (gazdasági és jogi megfontolások, piaci feltételek vagy a termékhez kötődő fogyasztói szokások) szerint (REKETTYE et al., 2015).

A tanulmányban azáltal kívánunk segítséget nyújtani azoknak a tejipari szereplőknek, akik a nemzetközi piacra lépésen gondolkodnak, hogy elvégeztünk egy nemzetközi piacszegmentációt. Épp ezért a kutatás során különös figyelmet fordítottunk rá, hogy a közlemény a gyakorlat szakemberei számára is épp úgy értéket képviseljen, mint a diszciplína tudományos múvelőinek. 


\section{Célkitưzés - ObJectives}

A kutatás célkitúzése egy nemzetközi piacszegmentáció végrehajtása az egy főre eső tejtermék-fogyasztási volumenek alapján. A piac szegmentációja azt jelenti, hogy a nagy, heterogén piacokat olyan kis, homogén egységekre bontjuk, amelyeken belül a fogyasztók szükségletei és igényei azonosak. Cél, hogy az eltérések a szegmenseken belül minimálisak, ugyanakkor a szegmensek között maximálisak legyenek. Számos szegmentációs szempont létezik, melyek alapvetően két fó megközelítés szerint csoportosíthatók. Az egyik csoport a fogyasztók jellemzői alapján vizsgálódik, míg a másik a termékhez füződő viszonyt veszi alapul (KOTLER és KELLER, 2012). Kutatásunk során mi az utóbbi szempont alapján végezzük el a nemzetközi szegmentációt, amelynek alapját különböző tejtermék-csoportok egy főre eső fogyasztási mennyisége képzi.

A szegmensképző ismérvek az egyes nemzetgazdaságok egy főre eső folyadéktej-, sajt(beleértve a túrót is), illetve vajfogyasztási mennyiségei három év átlagában (2012, 2013 és 2014). További cél a szegmentáció elvégzését követően, hogy jellemezzük a kialakított szegmentumokat az alábbi makro-tényezókkel:

- egy főre jutó bruttó hazai termék (GDP) USA dollárban (USD) kifejezve vásárlóerő-paritáson (PPP) számítva,

- egy före jutó bruttó nemzeti termék/jövedelem (GNI) USA dollárban kifejezve, vásárlóerő-paritáson (PPP) számítva,

- születéskor várható élettartam alapján,

- nyers halálozási ráta alapján,

- munkanélküliségi ráta szerint,

- valamint a háztartások fogyasztási kiadásai a bruttó hazai termék százalékában kifejezve.

A kutatás eredményei hozzájárulnak ahhoz, hogy feltárjuk, vajon miként szegmentálódnak az egyes országok a tejtermékek egy főre eső fogyasztási volumene szerint, és hazánk e szegmentumok között hol helyezkedik el. Továbbá a kutatás eredményeként fény derülhet arra, hogy az eltérő tejtermék-fogyasztási volumenú szegmensek a vizsgált makro-tényezőket tekintve miben és mennyiben különböznek egymástól.

\section{Módszertan - Methodology}

A kutatás alapjául szolgáló minta kiválasztása az IDF Bulletin 2015 kiadvány háttéradattáblái alapján történt. Ennek megfelelően a minta a háttéradatok között szereplő 46 nemzetgazdaságot és az Európai Uniót (EU28) tartalmazza, a háttéradattáblák között összesen 49 ország adatai szerepeltek, de ezek közül kettő a hiányzó adatok miatt kiesett. A szegmensek jellemzéséhez kiválasztott makro-tényezőket a The World Bank Data online elérhetô adatbázisából töltöttük le.

A piacszegmentáció elvégzése előtt a 2012., 2013. és 2014. év egy főre eső fogyasztási adatait termékenként átlagoltuk, hogy tompítsuk az esetleges évenkénti kiugrásokat az adatokban. A szegmentáció a klaszterelemzés különbözó módszereivel végezhető, mint például a hierarchikus és a partícionáló eljárások (FENYVES et al., 2017). A szegmentációt a HCPC módszerrel (Hierarchical Clustering on Principal Components), azaz fókomponens elemzésen alapuló hierarchikus klaszterelemzéssel végeztük el (ARGÜLLES et al., 2014). A klaszterelemzés elvégzését követően a kialakított klaszterek egymástól való különbözőségét varianciaelemzéssel, illetve Kruskal-Wallis-próbával vizsgáltuk. A kialakított szegmensek kapcsolatát a makro-tényezókkel varianciaelemzéssel és Kruskal-Wallis-próbával, illetve Tukey és Dunn post-hoc teszttel elemeztük. A varianciaanalízis normális eloszlási feltételének teljesülését a ferdeségi és csúcsossági mutatók alapján, a szórásegyezést pedig Levene-teszttel ellenőriztük. A kutatás során végül megvizsgáltuk, hogy milyen kapcsolatban állnak az egyes termékkategóriák egy főre eső fogyasztási volumenei és a vizsgált makro-tényezők, ezt a Pearson-féle lineáris korrelációval vizsgáltuk.

Az elemzést az R Statistics 3.4.2-es verziójával végeztük az $\mathrm{R}$ Studio szerkesztőben, a vizsgálatok során az alábbi bővítmények kerültek alkalmazásra: psych; factoextra; FactoMineR; Hmisc; corrplot; car; dunn.test és FSA (R Core Team, 2017). 


\section{EREDMÉNYEK - RESUlts}

\subsection{A mintasokaság leíró statisztikai elemzése - Descriptive Statistical Analysis of the Sample}

Szegmensképző ismérvek Segment Generating Criteria

A vizsgálatba 46 nemzetgazdaságot, valamint az Európai Uniót (EU28) vontuk be, amelynek átlagértékeit a tagállamok adatainak súlyozott adatai adták. A vizsgált országok egy főre eső folyadéktej-fogyasztásának átlaga 57,39 kilogramm/fö/év 31,13 kg/fö/év szórás mellett. A legkisebb egy főre eső tejfogyasztás a vizsgált három év átlaga alapján Mongóliában jellemző 9,53 kg/fő fogyasztás mellett, míg a legtöbb tejet, átlagosan évi 130,77 kilogrammot a finnek fogyasztják fejenként. Sajtfogyasztás tekintetében a mintaátlag 12,44 kg/fó/év $7,65 \mathrm{~kg} /$ fö/ év szórással. A legkevesebb sajtot ebben az esetben is a mongolok fogyasztanak, alig évi o,3 kilogrammot fejenként, míg a legtöbb sajtot $26,33 \mathrm{~kg}$ /fóvel a franciák veszik magukhoz évente. A vaj esetében az átlag fogyasztás évi $2,38 \mathrm{~kg} /$ fó és a szórás $1,83 \mathrm{~kg} /$ fó. A minimum évi $0,1 \mathrm{~kg} /$ fó (Kína) a maximum pedig $7,77 \mathrm{~kg} /$ fő (Franciaország). Magyarország egy főre eső folyadéktej- és sajt- (beleértve a túrót) fogyasztása nagyjából a középmezőnyben helyezkedik el, míg vajfogyasztása jelentősen elmarad a mintaátlagtól. Tejból átlagosan évi 49,8 kg/fő a fogyasztás a vizsgált három évben, folyamatosan csökkenő tendencia mellett, sajtból évi 11,37 kg-ot veszünk magunkhoz fejenként, míg vajból 1,07 kg-ot. Az egy főre eső fogyasztási adatok országonként az 1a. és 1b. táblázatokban láthatók.
A szegmensek jellemzéséhez használt makro-tényezók - The Applied Macro-factors for Characterizing the Segments

A vizsgált 46 ország, valamint az Európai Unió közül vásárlóerő-paritáson számítva az egy főre eső bruttó hazai termék 2012, 2013 és 2014 átlagában Ukrajnában a legkisebb 8596 USD értékkel, míg Norvégiában a legnagyobb, ahol ez az érték 65998 USD. Az átlag 31338 USD, ehhez képest hazánk az átlag alatt van, nálunk az egy főre jutó GDP a három év átlagában 24286 USD volt. Ehhez képest minimális eltéréseket láthatunk az egy före jutó bruttó nemzeti jövedelem esetében, épp emiatt ezt nem is részletezzük. A munkanélküliségi ráta a három év átlagát tekintve Magyarországon 9,64\% volt, ami az átlag fölött van, de jelentősen elmarad a 25,11\%-os maximumtól (Spanyolország). A legalacsonyabb munkanélküliségi ráta a vizsgált országok közül Dél-Koreában volt (3,27\%). A háztartások fogyasztási kiadása a GDP százalékában nálunk 52,03\% volt a vizsgált három évet tekintve, ami az átlag $(56,82 \%)$ alatti érték. A legmagasabb születéskor várható élettartam a három év átlagában Japánra jellemzó (több mint 83 év), míg a Dél-Afrikai Köztársaságban a legalacsonyabb (56,7 év). Magyarországon több mint 75 év a születéskor várható átlagos élettartam, ami a vizsgált országok átlagától alig marad el (77 év). A nyers halálozási ráta hazánkban $12,87 \%$, ami sokkal magasabb a mintaátlaghoz képest (8,87\%). A legalacsonyabb értéket Iránban mérték (4,69\%), míg a legmagasabbat Bulgáriában (14,83\%). 
1a. TÁBLÁZAT

TABLE $1 a$

A vizsgált tejtermék-kategóriák fogyasztási adatai a folyadéktej-fogyasztás szerint csökkenó sorrendben

(Consumption of the Examined Product Categories in Descending Order of Liquid Milk Consumption)

\begin{tabular}{|c|c|c|c|}
\hline \multirow{2}{*}{ Ország (Country) } & \multicolumn{3}{|c|}{$\begin{array}{l}\text { Egy fóre esó fogyasztás a 2012., 2013. és } 2014 \text {. évek átlagában (kg/fó) } \\
\text { (Mean of consumption in } 2012,2013 \text { and } 2014 \text { in } \mathrm{kg} \text { per capita) }\end{array}$} \\
\hline & $\begin{array}{l}\text { Folyadéktej } \\
\text { (Liquid milk) }\end{array}$ & $\begin{array}{l}\text { Sajt (és túró) (Cheese } \\
\text { and cottage cheese) }\end{array}$ & $\underset{\text { (Butter) }}{\text { Vaj }}$ \\
\hline Finnország (Finland) & 130,8 & 24,7 & 3,9 \\
\hline Írország (Ireland) & 120,6 & 11,1 & 2,4 \\
\hline Észtország (Estonia) & 118,8 & 21,3 & 2,1 \\
\hline Ausztrália (Australia) & 109,8 & 13,5 & 3,9 \\
\hline Egyesült Királyság (UK) & 107,0 & 11,6 & 3,2 \\
\hline Új-Zéland (New Zealand) & 101,2 & 8,7 & 4,8 \\
\hline Izland (Iceland) & 96,6 & 25,4 & 5,3 \\
\hline Dánia (Denmark) & 90,3 & 21,4 & 3,7 \\
\hline Svédország (Sweden) & 90,1 & 20,1 & 2,5 \\
\hline Norvégia (Norway) & 85,1 & 18,2 & 3,0 \\
\hline Spanyolország (Spain) & 82,2 & 9,4 & 0,5 \\
\hline Kanada (Canada) & 77,8 & 12,3 & 2,8 \\
\hline Ausztria (Austria) & 77,2 & 20,4 & 5,2 \\
\hline USA (USA) & 73,9 & 15,3 & 2,5 \\
\hline Svájc (Switzerland) & 65,3 & 21,4 & 5,3 \\
\hline EU28 (EU28) & 62,9 & 18,4 & 3,7 \\
\hline Horvátország (Croatia) & 64,8 & 10,3 & 1,1 \\
\hline Uruguay (Uruguay) & 63,9 & 6,3 & 1,5 \\
\hline Brazília (Brazil) & 60,1 & 3,7 & 0,4 \\
\hline $\begin{array}{l}\text { Csehország (Czech } \\
\text { Republic) }\end{array}$ & 59,0 & 16,3 & 5,0 \\
\hline Németország (Germany) & 54,4 & 24,4 & 6,2 \\
\hline Izrael (Israel) & 54,4 & 16,4 & 0,9 \\
\hline Kolumbia (Columbia) & 53,9 & 0,9 & 0,1 \\
\hline Franciaország (French) & 53,7 & 26,3 & 7,8 \\
\hline Olaszország (Italy) & 53,1 & 20,7 & 2,3 \\
\hline Szlovákia (Slovakia) & 50,6 & 11,1 & 3,1 \\
\hline Belgium (Belgium) & 50,3 & 15,1 & 2,4 \\
\hline $\begin{array}{l}{ }^{1} \text { Magyarország } \\
\text { (Hungary) }\end{array}$ & $49,8(27)$. & $11,4(27)$. & $1,1(30-31)$. \\
\hline $\begin{array}{l}\text { Hollandia } \\
\text { (The Netherlands) }\end{array}$ & 48,0 & 20,5 & 3,0 \\
\hline Argentína (Argentina) & 44,2 & 12,4 & 0,9 \\
\hline
\end{tabular}

${ }^{1}$ Magyarország esetében az adatokat összehasonlítva a hazai adatbázisokkal jelentős eltéréseket tapasztaltunk, de a vizsgálatban az IDF Bulletin (2015) adatai mellett maradtunk, mivel a kiadvány háttéradat-táblái nagyobb összhangot mutattak a nemzetközi adatbázisokkal.

Forrás (Source): IDF Bulletin (2015) alapján saját számítás (Own calculation based on IDF Bulletin (2015)) 
SzAKÁLy, Z. - KISS, M. - GÁL, T. - KováCS, B.

1b. TÁBLÁZAT

TABLE 1 b

A vizsgált tejtermék-kategóriák fogyasztási adatai a folyadéktej-fogyasztás szerint csökkenő sorrendben

(Consumption of the Examined Product Categories in Descending Order of Liquid Milk Consumption)

\begin{tabular}{|c|c|c|c|}
\hline \multirow{2}{*}{ Ország (Country) } & \multicolumn{3}{|c|}{$\begin{array}{l}\text { Egy före esố fogyasztás a 2012., } 2013 . \text { és } 2014 \text {. évek átlagában (kg/fö) } \\
\text { (Mean of consumption in } 2012,2013 \text { and } 2014 \text { in } \mathrm{kg} \text { per capita) }\end{array}$} \\
\hline & $\begin{array}{l}\text { Folyadéktej } \\
\text { (Liquid milk) }\end{array}$ & $\begin{array}{l}\text { Sajt (és túró) (Cheese } \\
\text { and cottage cheese) }\end{array}$ & $\underset{\text { (Butter) }}{\text { Vaj }}$ \\
\hline Lettország (Latvia) & 38,0 & 16,5 & 2,6 \\
\hline Lengyelország (Poland) & 38,1 & 15,7 & 4,0 \\
\hline Oroszország (Russia) & 35,2 & 5,9 & 2,4 \\
\hline Dél-Korea (South Korea) & 33,2 & 2,1 & 0,2 \\
\hline Mexikó (Mexico) & 32,7 & 3,5 & 0,4 \\
\hline Litvánia (Lithuania) & 31,7 & 18,7 & 2,8 \\
\hline Japán (Japan) & 30,9 & 2,2 & 0,6 \\
\hline Kazahsztán (Kazakhstan) & 27,9 & 2,6 & 1,4 \\
\hline $\begin{array}{l}\text { Dél-Afrikai Köztársaság } \\
\text { (Republic of South Africa) }\end{array}$ & 26,2 & 1,8 & 0,4 \\
\hline Irán (Iran) & 25,5 & 4,9 & 0,3 \\
\hline Chile (Chile) & 23,5 & 8,6 & 1,2 \\
\hline Ukrajna (Ukraine) & 21,5 & 4,4 & 1,6 \\
\hline Bulgária (Bulgaria) & 20,5 & 16,2 & 0,9 \\
\hline Egyiptom (Egypt) & 19,0 & 4,5 & 0,8 \\
\hline Törökország (Turkey) & 17,1 & 7,5 & 0,8 \\
\hline Kína (China) & 17,0 & 0,0 & 0,1 \\
\hline Mongólia (Mongolia) & 9,5 & 0,3 & 0,6 \\
\hline
\end{tabular}

Forrás (Source): IDF Bulletin (2015) alapján saját számítás (Own calculation based on IDF Bulletin (2015))

\subsection{A nemzetközi piacszegmentáció eredményei - Results of International Market Segmentation}

A szegmensképző ismérveink (egy főre eső folyadéktej-, sajt- és vajfogyasztás) a klaszterelemzés követelményeinek megfelelnek. A hagyományos klaszterelemzési módszerekkel azonban nem alakíthatók ki homogén klaszterek (ezek esetében a relatív szórás klaszterenként és változónként legalább 50\% fölötti) éppen ezért a fókomponens-analízisen (PCA) alapuló hierarchikus módszert választottuk a szegmentáció elvégzésére, az így létrejött klasztereink elemszámai kiegyensúlyozottabbak, a relatív szórások alacsonyabbak és a kialakított klaszterek/szegmensek szakmailag értelmezhetőbbek. A 2. táblázatban a létrejött klaszte- reket mutatjuk be az egy főre eső fogyasztási adatok átlagai, valamint a szórások, a maximum és minimum értékek segítségével.

A klaszterek elemszámai kiegyenlítettek, doboz ábrákon (box plot) a klaszterek a különböző termékek egy főre eső fogyasztási adatai alapján jól elkülönülnek. A klaszterelemzés eredményeit varianciaelemzéssel, illetve Kruskal-Wallis-próbával validáltuk. Az eredmények alapján megállapítható, hogy a klaszterek szignifikánsan különböznek egymástól nemcsak 95, hanem 99\%-os megbízhatósági szint mellett is.

Az első klaszterbe azok az országok kerültek, ahol mind a folyadéktej-, mind a sajt-, mind pedig a vajfogyasztás egy főre eső értéke alacsonynak tekinthető. Ezek a következők: Dél-Afrikai Köztársaság, Egyiptom, Ukrajna, 
Chile, Kolumbia, Brazília, Mexikó, Mongólia, Kazahsztán, Törökország, Dél-Korea, Irán, Japán, Kína.

A második klaszterbe azok az országok tartoznak, amelyekben az egy före eső fogyasztás közepesnek tekinthető: Oroszország, Uruguay, Argentína, Kanada, Amerikai Egyesült Államok, Lettország, Litvánia, Bulgária, Horvátország, Szlovákia, Magyarország, Belgium, Hollandia, Lengyelország, Olaszország, Spanyolország, Izrael.

A harmadik klaszterben a mintához képest magas egy főre eső fogyasztású országok talál- hatók: Új-Zéland, Ausztrália, Izland, Norvégia, Svájc, Észtország, Dánia, Írország, Csehország, Ausztria, Finnország, Svédország, Franciaország, Németország, Egyesült Királyság és az Európai Unió (EU28).

A vizuális áttekinthetőség érdekében a szegmentumokat egy vaktérképen is megjelöltük (1. ábra), a térképen világosszürke színnel az alacsony fogyasztású, sötétszürke színnel a közepes fogyasztású, míg feketével a magas tejtermék-fogyasztású országok jelennek meg, míg a fehér színnel jelölt országok nem szerepeltek a vizsgálatban.

2. TÁBLÁZAT

TABLE 2

A szegmentáció eredményeit összefoglaló tábla (kg/fó) N=47

(Summary Table of Results of Segmentation, kg per capita)

\begin{tabular}{|c|c|c|c|c|c|}
\hline $\begin{array}{l}\text { Klaszter } \\
\text { (Cluster) }\end{array}$ & $\begin{array}{c}\text { Termék } \\
\text { (Product) }\end{array}$ & $\begin{array}{c}\text { Átlag } \\
\text { (Mean) }\end{array}$ & $\begin{array}{c}\text { Szórás } \\
\text { (Std. deviaton) }\end{array}$ & $\underset{\text { (Min) }}{\operatorname{Min}}$ & $\underset{(\operatorname{Max})}{\operatorname{Max}}$ \\
\hline \multirow{3}{*}{ 1. $(\mathrm{N}=14)$} & tej (milk) & 28,43 & 13,83 & 9,53 & 60,07 \\
\hline & sajt (cheese) & 3,37 & 1,52 & 0,03 & 8,63 \\
\hline & vaj (butter) & 0,63 & 0,40 & 0,10 & 1,63 \\
\hline \multirow{3}{*}{ 2. $(\mathrm{N}=17)$} & tej (milk) & 51,56 & 16,82 & 20,53 & 82,2 \\
\hline & sajt (cheese) & 13,79 & 4,41 & 5,87 & 20,67 \\
\hline & vaj (butter) & 2,17 & 1,01 & 0,53 & 4,00 \\
\hline \multirow{3}{*}{$3 \cdot(\mathrm{N}=16)$} & tej (milk) & 88,90 & 24,95 & 53,73 & 130,77 \\
\hline & sajt (cheese) & 18,94 & 5,41 & 8,67 & 26,33 \\
\hline & vaj (butter) & 4,25 & 1,52 & 2,07 & 7,77 \\
\hline
\end{tabular}

Forrás (Source): IDF Bulletin (2015) alapján saját számítás (Own calculation based on IDF Bulletin (2015))

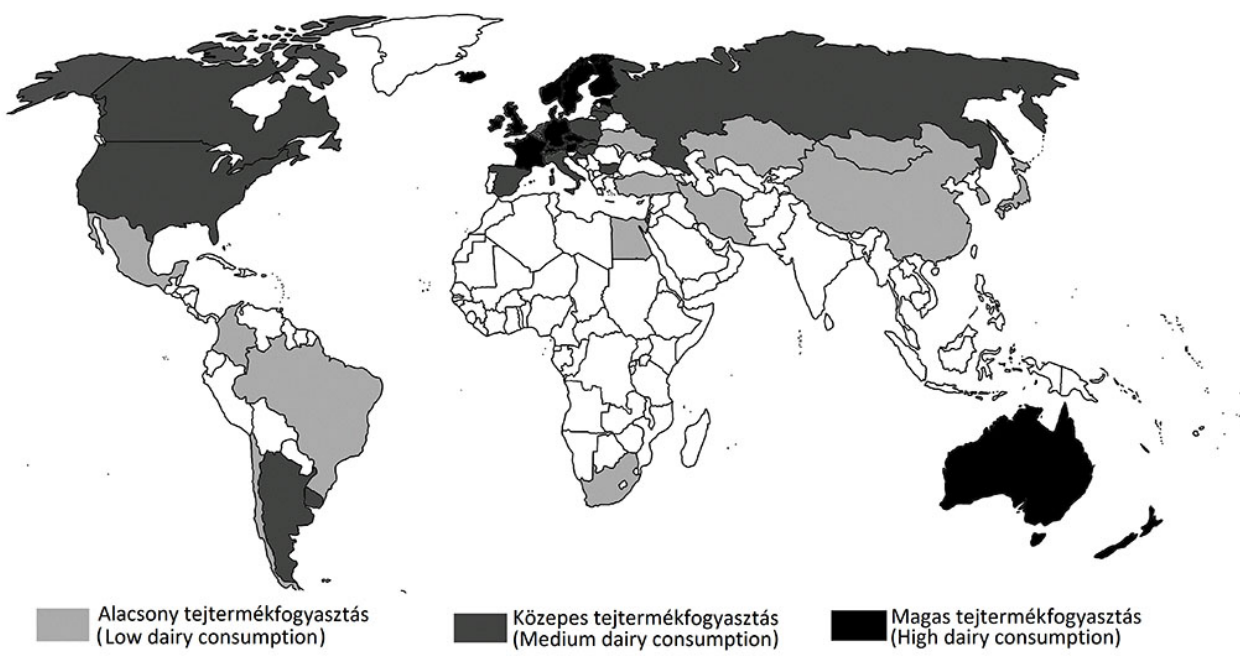

\section{1. ÁBRA}

A szegmentumok földrajzi elhelyezkedése (Location of Segments)

FIG. 1

Forrás (Source): IDF Bulletin (2015) alapján saját szerkesztés (Own compilation based on IDF Bulletin (2015)) 


\subsection{A kialakított szegmentumok vizsgálata a makro-változókkal - Examination of Formed Segments with Macro-Variables}

Mivel a bruttó hazai termék (GDP) és a bruttó nemzeti jövedelem (GNI) egyaránt a nemzetgazdaság teljesítményét mérő mutató, és a kettő között szoros kapcsolat van (a különbség a belföldiek külföldön megtermelt elsődleges jövedelme és a külföldiek belföldön megtermelt elsődleges jövedelmében mutatkozik), így e kettő bemutatása egyben történik. Varianciaelemzés alapján a kialakított szegmensek között szignifikáns különbség tapasztalható a GDP és a GNI tekintetében is. Azt, hogy ez a különbség mely szegmentumoknál jelentkezik, Tukey post-hoc teszttel határoztuk meg. 99\%os megbízhatósági szint mellett megállapítható, hogy az alacsony, a közepes és a magas egy fôre eső fogyasztási volumenü klaszterek mind különböznek egymástól. A 2. ábrán látható az átlagos GDP és GNI szegmentumok szerint.

\section{2. ÁBRA}

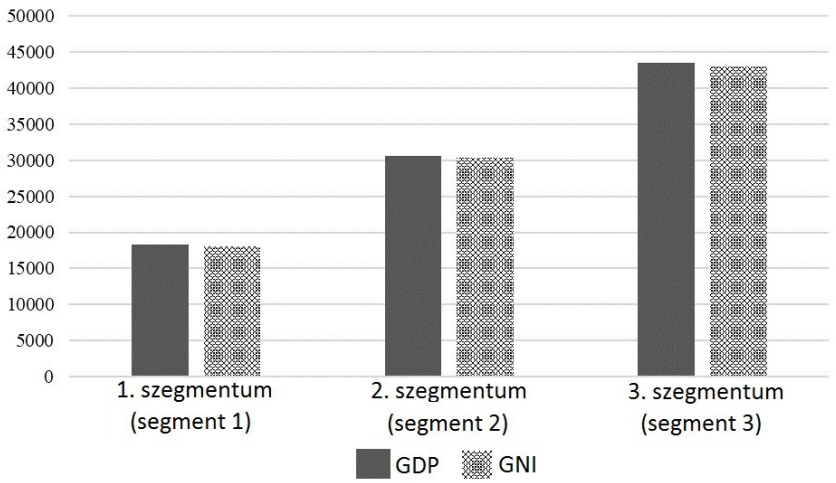

\section{A GDP és a GNI átlaga klaszterenként (Means of GDP and GNI per Segments)}

Forrás (Source): Saját szerkesztés saját számítások alapján (Own compilation based on own calculations)

Jól látható az ábrán, hogy a magasabb egy före eső tejtermékfogyasztással rendelkező szegmentumok esetében jelentősen magasabb a GDP és a GNI átlagértéke vásárlóerő-paritáson számítva. Oksági kapcsolat feltárása nem történt, de feltételezhető, hogy a magasabb jövedelmü országokban a magasabb jövedelem miatt többet költhetnek ezekre a termékekre, azaz a gazdagabb országokban vagy a fogyasztás magasabb aránya miatt több a tej-, sajt- és vajfogyasztás, vagy a magasabb jövedelmű országokban a fogyasztói társadalom megengedheti magának, hogy más, „alacsonyabb rendü termékeket” (inferior javakat) tejtermékekkel helyettesítsen.

A GDP és GNI mellett érdemes figyelembe venni a háztartások fogyasztási kiadásainak mértékét a GDP százalékában kifejezve. Ez esetben 95\%-os megbízhatósági szint mellett a varianciaelemzés alapján szignifikáns különbség van a szegmentumok között. Tukey posthoc teszttel tovább elemezve a különbség csak az alacsony és a magas egy főre eső fogyasztási volumenü szegmens között szignifikáns 95\%-os megbízhatósági szinten, a közepes és a magas fogyasztási volumenű klaszter között a különbség csak 90\%-os megbízhatósággal fogadható el. Az 1. szegmentumba tartozó országok háztartásainak átlagos fogyasztási kiadásai a bruttó hazai termék százalékában kifejezve 59,47\%, a 2. szegmentum esetében $58,70 \%$, míg a 3 ., magas egy főre eső tej-, sajt- és vajfogyasztási volumenú szegmentumnál 52,51\%. Azaz, ahol a megtermelt jövedelem nagyobb hányada kerül fogyasztásra, ott alacsonyabb a tejtermékek fogyasztási mennyisége, míg ahol a megtermelt jövedelem kisebb hányadát fogyasztják el, ott magasabb a tejtermékfogyasztás egy fơre eső mennyisége. Erre ésszerű magyarázat lehet, hogy a GDP és a háztartások GDP-ben kifejezett fogyasztási arányának a kapcsolata közepesen erős és ellentétes $(r=-0,46)$. Ez azzal indokolható, hogy a magasabb jövedelmű országok a megtermelt jövedelem kisebb hánya- 
dát fordítják fogyasztásra, azaz alacsonyabb a fogyasztási hányad, mert a jövedelem kisebb része is elegendő a szükséges fogyasztási szint eléréséhez, és a háztartások jövedelmük fennmaradó részét megtakarításra fordíthatják.

A munkanélküliségi ráta vonatkozásában nem állapítható meg szignifikáns eltérés a szegmentumok között a Kruskal-Wallis-próba alapján 95\%-os megbízhatósági szintet tekintve.

A makrogazdaság egészségügyi-demográfiai mutatói közül talán a két legfontosabb a születéskor várható élettartam és a halálozási ráta. A kutatás során e két tényezôt is figyelembe vettük a gazdasági teljesítményt tükröző mutatók mellett. A Kruskal-Wallis-féle nemparaméteres próba alapján szignifikáns különbség van a szegmentumok között a várható élettartam tekintetében 99\%-os megbízhatósági szint mellett. A Dunn-féle post-hoc teszt alkalmazásával megállapítottuk, hogy az első és a harmadik szegmentum 99\%-os megbízhatósággal különbözik, a második és a harmadik pedig 90\%-os megbízhatósággal tér el egymástól. A szegmentumonkénti eltérések bemutatása doboz ábra segítségével történik (3. ábra). Az ábra vízszintes tengelyén az egyes szegmensek láthatók; az 1. az alacsony, a 2. a közepes, míg a 3. a magas tejtermék-fogyasztású szegmentumot jelöli. A függőleges tengelyen a születéskor várható élettartam látható. Az ábráról leolvasható a terjedelem, az interkvartilis terjedelem, a medián, a minimum és a maximum érték. Az interkvartilis terjedelmet szegmentumonként egy téglalap jelöli, ebben van behúzva a medián vastag vonallal, a legnagyobb és legkisebb értékek pedig egy-egy talppal vannak ábrázolva. A doboz elhelyezkedése a teljes talphoz viszonyítva, illetve a medián helyzete a dobozon belül információt ad az eloszlásról. A dobozban (téglalapban) található klaszterenként az országok 50\%-a, míg a két talp 25-25\%-át ábrázolja szegmentumonként az országoknak (HUZSVAI, 2012).

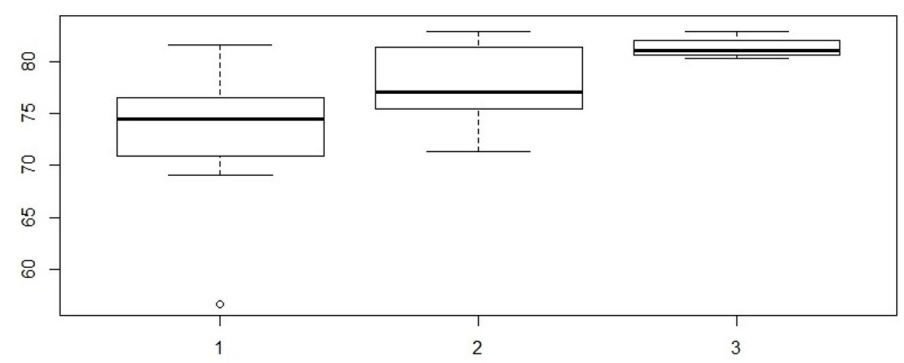

3. ÁBRA

A születéskor várható élettartam szegmentumonként (Life Expectancy per Segments)

Forrás (Source): Saját szerkesztés saját számítások alapján (Own compilation based on own calculations)

A várható élettartam az első szegmentumnál átlagosan 73,9 év, a másodiknál 77,78 év, a harmadik szegmens esetében pedig 81,01 év. Jól látható, hogy az egy före eső tej-, sajt- és vajfogyasztás mennyiségének növekedésével párhuzamosan a várható élettartam is emelkedik. Természetesen ez szoros összefüggésben állhat a nemzetgazdaság jövedelmével, amiről már korábban írtunk, vagyis a magasabb tejtermék-fogyasztású országokban magasabb a GDP is, ami hatással lehet a születéskor várható élettartamra.

A nyers halálozási ráta esetében varianciaelemzés alapján szintén szignifikáns a különb- ség 99\%-os megbízhatósági szint mellett (4. ábra). Tukey-tesztet alkalmaztunk a páronkénti különbözőségek megállapítására, ez alapján szignifikáns különbség egyedül az első és a második klaszter között fedezhető fel (sig=0,006). Az eredmények értelmezhetőségét jelen esetben jelentős mértékben rontja, hogy a közepes tejtermék-fogyasztású szegmentum esetében a halálozási ráta szórása nagy. Ez a dobozábrán a terjedelemből, az alsó és felső negyed méretéből is látszik. Az első szegmentumnál a halálozási ráta átlagosan 7,31\%, a másodiknál 10,27\%, míg a harmadiknál 8,74\%. 


\section{4. ÁBRA}

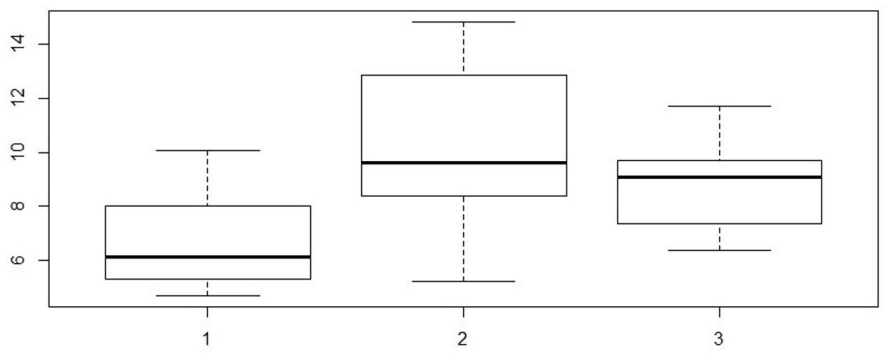

A halálozási ráta szegmentumonként (Mortalitiy Rate per Segments)

FIG. 4

Forrás (Source): Saját szerkesztés saját számítások alapján (Own compilation based on own calculations)

\subsection{A tejtermékek fogyasztása és a makro-változók lineáris kapcso- latának vizsgálata - Examination of the Linear Relationship of Milk Product Consumption and Macro Variables}

A nemzetközi piacszegmentáció mellett érdemes megvizsgálni, hogy milyen lineáris kapcsolat fedezhető fel a tejtermékek egy főre jutó fogyasztási volumene és a makro-változók között. A makro-változókat érintő kapcsolatvizsgálat részletesebben is rávilágíthat a köztük lévő összefüggésekre. A 3. táblázatban láthatóak a Pearson-féle lineáris korrelációs együtthatók. Az együttható értéke -1 és +1 között lehet, ami azt jelenti, hogy minél közelebb van abszolút értékben az együttható az egyhez, annál erősebb a kapcsolat, a pozitív érték pedig azt jelenti, hogy a két változó együtt változik, vagyis, ha az egyik értéke nő, a másik is nő, míg a negatív érték ennek az ellenkezője, azaz, ha nő az egyik érték a másik csökken. Továbbá a táblázatban megjelenítettük azt is, hogy a t-próba alapján mely koefficiensek szignifikánsak, milyen megbízhatósági szint mellett.

Közepesen erős pozitív kapcsolat van az egyes tejtermékek egy före eső fogyasztási mennyisége között. Azaz, ahol egyik termékből többet fogyasztanak, ott a másik termékből is nagyobb a fogyasztási szint. Már-már erős po- zitív kapcsolatnak tekinthető a termékek és a nemzetgazdaság teljesítményét (GDP, GNI) mérő mutatók viszonya. Ez igazolja a szegmentumoknál tett megállapításunkat, mely szerint a nagyobb gazdasági teljesítményű országokban nagyobb az egy főre eső fogyasztási volumen is, továbbá szintén pozitív és közepes erősségű a kapcsolat a tejtermékek fogyasztási mennyisége és a születéskor várható élettartam között. Azonban, ha megnézzük, hogy a várható élettartam sokkal erősebb lineáris kapcsolatban van a GDP-vel és GNI-jal, nem zárható ki a GDP/GNI áttételes hatása. Azaz azért is lehet magasabb a várható élettartam a nagyobb egy főre eső tejtermék-fogyasztású országokban, mert az egy főre eső GDP és GNI is nagyobb. A szakmai igényességet egy pillanatra mellőzve, ez összefoglalható úgy, hogy a gazdagabb országokban tovább élnek az emberek és több tejterméket fogyasztanak. Természetesen azt fontos kihangsúlyoznunk, hogy e vizsgálatok alapján ok-okozati kapcsolat nem állapítható meg. Nem szignifikáns azonban a tejtermékek egy főre eső fogyasztási volumenének korrelációs együtthatója a munkanélküliségi rátával, a GDP százalékában meghatározott háztartások fogyasztási kiadásával és a nyers halálozási rátával, azaz köztük nem állapítható meg lineáris összefüggés. 
A változók közötti Pearson-féle lineáris korrelációs együttható (Pearson Linear Correlation Coefficients Between the Variables)

\begin{tabular}{|c|c|c|c|c|c|c|c|c|c|}
\hline & P1 & P2 & P3 & GDP & GNI & Le. & u.r. & c & m.r. \\
\hline P1 & $1^{*}$ & $0,52^{*}$ & $0,45^{*}$ & $0,63^{*}$ & $0,6^{*}$ & $0,54^{*}$ & $-0,06$ & $-0,28$ & $-0,07$ \\
\hline $\mathrm{P} 2$ & $0,52^{*}$ & $1^{*}$ & $0,77^{*}$ & $0,67^{*}$ & $0,67^{*}$ & $0,55^{*}$ & $-0,09$ & $-0,23$ & 0,26 \\
\hline $\mathrm{P}_{3}$ & $0,45^{*}$ & $0,77^{*}$ & $1^{*}$ & $0,63^{*}$ & $0,62^{*}$ & $0,46^{* * *}$ & $-0,24$ & $-0,21$ & 0,15 \\
\hline GDP & $0,63^{*}$ & $0,67^{*}$ & $0,63^{*}$ & $1^{*}$ & $1^{*}$ & $0,73^{*}$ & $-0,31^{* *}$ & $-0,46^{*}$ & $-0,09$ \\
\hline GNI & $0,6^{*}$ & $0,67^{*}$ & $0,62^{*}$ & $1^{*}$ & $1^{*}$ & $0,72^{*}$ & $-0,32^{* *}$ & $-0,44^{*}$ & $-0,08$ \\
\hline Le. & $0,54^{*}$ & $0,55^{*}$ & $0,46^{*}$ & $0,73^{*}$ & $0,72^{*}$ & $1^{*}$ & $-0,4^{*}$ & $-0,3^{* *}$ & $-0,3^{* * *}$ \\
\hline u.r. & $-0,06$ & $-0,09$ & $-0,24$ & $-0,31^{* *}$ & $-0,32^{* *}$ & $-0,4^{*}$ & $1^{*}$ & $0,25^{* * *}$ & $0,31^{* * *}$ \\
\hline c & $-0,28$ & $-0,23$ & $-0,21$ & $-0,46^{*}$ & $-0,44^{*}$ & $-0,3^{* * *}$ & $0,25^{* * *}$ & $1^{*}$ & 0,11 \\
\hline m.r. & $-0,07$ & 0,26 & 0,15 & $-0,09$ & $-0,08$ & $-0,3^{* *}$ & $0,31^{* * *}$ & 0,11 & $1^{*}$ \\
\hline
\end{tabular}

Forrás (Source): Saját számítások (Own calculations)

${ }^{*} \mathrm{p}<0,01 ;{ }^{* *} \mathrm{p}<0,05 ;{ }^{* * *} \mathrm{p}<0,1$

P1: tej, P2: sajt; P3: vaj; GDP: egy főre eső bruttó hazai termék; GNI: egy főre eső bruttó nemzeti jövedelem; Le.: születéskor várható élettartam; u.r.: munkanélküliségi ráta; c: háztartások fogyasztási kiadásai a GDP százalékában; m.r.: nyers halálozási ráta

(P1: milk; P2: cheese; P3: butter; GDP: gross domestic product per capita; GNI: gross national income per capita; Le.: life expectancy; u.r.: unemployement rate; c: household consumption in GDP; m.r.: mortality rate)

\section{KöVETKEZTETÉSEK -} CONCLUSIONS

Az eredmények alapján mindenekelőtt megállapítható, hogy a három tejtermék-kategória egy főre eső fogyasztási volumenei alapján jól elkülönülő szegmentumokat kaptunk. A legkisebb fogyasztással bíró klaszterbe tartozik a vizsgált országok 29,8\%-a, a közepes fogyasztásúak közé az államok 36,2\%-a, míg a legnagyobb fogyasztásúak képezik a minta 34,0\%-át. A szórásértékek egyértelműen nőnek a tejtermékfogyasztás emelkedésével, ami azt jelenti, hogy az e téren fejlettnek tekinthető országok fogyasztási szintjei között nagyobb különbségek tapasztalhatók, mint a kisebb fogyasztású államokban.

Egyértelmú szignifikáns kapcsolat van a tejtermékfogyasztás és a nemzetgazdaság teljesítményét mérő mutatók (GDP, GNI) között, vagyis a fejlettebb országok tejtermékfogyasztása szignifikánsan nagyobb, mint a szegényebbeké. Ez igazolja azt a szakmai körökben jól ismert tételt, amely szerint egy ország fejlettségi szintje alapvetően meghatározza az élelmiszerfogyasztás szerkezetét. Feltételezhető, hogy a magas jövedelem miatt a fejlett országok vásárlói többet költenek folyadéktejre, sajtfélékre és nem utolsósorban vajfélékre, mint a szegé- nyebb államok lakói, gyakran tejtermékekkel helyettesítve az „alacsonyabb rendú termékeket”. Azonban a háztartások fogyasztási kiadásainak tekintetében pont ellentétes kapcsolatot találtunk, azokban az országokban, ahol a megtermelt jövedelem nagyobb részét fordítják a háztartások fogyasztási javakra, kisebb a tejtermékfogyasztás egy főre eső volumene. Pozitív összefüggést tapasztaltunk a születéskor várható élettartam és az egy főre eső tejtermékfogyasztás mennyisége között is. Bár a halálozási ráta a szegmentumok összehasonlítása során csak korlátozottan értelmezhető, ennek okára alaposabban rávilágít a korrelációs táblázat, ahol láthatjuk, hogy a halálozási ráta és a tejtermékek egy före eső fogyasztási volumene közt nincs érdemi korrelációs kapcsolat. A munkanélküliségi ráta esetében szintén nem találtunk szignifikáns eltéréseket a szegmentumok között.

Összefoglalva megállapítható, hogy Magyarországon a vizsgált tejtermék-kategóriák fogyasztása közepesnek tekinthető, vagyis hazánk a második szegmensbe tartozik. A szegmensben Magyarország mellett további hét volt szocialista ország található, ami mutatja a régió kulturális hasonlóságát. Hazánk számára kiemelkedően fontos stratégiai feladat a tejtermékfogyasztás növelése a közösségi marketing 
eszközeivel. A közösségi marketingstratégia célja a tejágazatban az egyensúlyi állapot létrehozásának, majd tartós fenntartásának elősegítése a tejtermelés, valamint a feldolgozott tej és tejtermékek értékesítése között. Az egyensúly létrehozásában elsődleges szerepe van a belföldi fogyasztás növelésének, de a gazdaságos export bővítése is fontos eszköze az egyensúly fenntartásának (SÁROSI, 2003). A tejtermékek fogyasztása megfelelő pozícionálással és tudatos kommunikációval stabil növekedési pályára állhat. Ehhez azonban rendbe kell tenni a kategória imázsát, hangsúlyozni kell a tejtermékek egészségességét és táplálkozási előnyeit, majd korrigálni kell a fogyasztói tévhiteket. A tejtermékekre irányuló marketingkommunikációban két fő irányt lehet megkülönböztetni. A klasszikus irányt a tejtermékek egészségvédő funkcióinak hangsúlyozása jelenti, a modern irányt pedig azok az értékek képviselik (életélvezet, esztétikus megjelenés, fittség stb.), amelyek elsősorban a fiatal fogyasztók megnyerésére koncentrálnak (differenciált marketing). Kedvező tendencia, hogy ezek az értékek már megjelentek a hazai fogyasztók élelmiszerválasztási mechanizmusában is.

\section{KöSZÖNETNYILVÁNÍTÁS - ACKNOWLEDGEMENT}

A publikáció létrehozását a Debreceni Egyetem EFOP-3.6.2-16-2017-00003 „Sport- Rekreációs- és Egészséggazdasági Kooperációs Kutatóhálózat létrehozása" című projektje támogatta.

\section{IRODALOMJEGYZÉK - REFERENCES}

Argülles, M. - Benavides, C. Fernández, I. (2014): A New Approach to the Identification of Regional Clusters: Hierarchical Clustering on Principal Components. Applied Economics. 46 (21) 2511-2519. https://doi.org/10.1080/ooo3 6846.2014 .904491
Fenyves, V. - Tarnóczi, T. - Nagy, A. (2017): Pénzügyi kimutatások elemzése klaszterelemzés segítségével az ÉszakAlföld régióban múködő élelmiszerkiskereskedelmi vállalkozásoknál. Acta Carolus Robertus: Károly Róbert Fóiskola Gazdaság- És Társadalomtudományi Kar Tudományos Közleményei. 7 (1) 87-103.

Huzsvai, L. (2012): Statisztika gazdaságelemzők részére, Excel és $R$ alkalmazások. Seneca Books.

IDF Bulletin (2015): The World Dairy Situation 2016. Bulletin of the International Dairy Federation.

Józsa, L. (2014): Marketingstratégia. Akadémiai Kiadó, Budapest.

Kotler, P. - Keller, K. L. (2012): Marketingmenedzsment. Akadémia Kiadó, Budapest.

R Core Team (2017): R: A Language and Environment for Statistical Computing. R Foundation for Statistical Computing. Vienna, Austria. URL https://www.Rproject.org/.

Rekettye, G. - Tóth, T. - Malota, E. (2015): Nemzetközi marketing. Akadémiai Kiadó, Budapest.

Sárosi, I. (2003): A tejvertikum középtávú közösségi marketingstratégiája. FVMAMC tanulmány, Budapest.

Szakály,S. (1999): Aktuális gazdaságpolitikai intézkedések a magyar tejgazdaság pozíciójának megerősítésére az EU-ba való belépésig. FVM-AMC tanulmány, Budapest.

Szakály, Z. (2013): A tejgazdasági marketing helyzete és aktuális feladatai Magyarországon. Tejgazdaság. 73 (1-2) 35-44.

Szakály, Z. (2017): Tejipari marketing. (In: Szakály Z. szerk.: Élelmiszer-marketing. 1-518). Akadémiai Kiadó, Budapest, 429439. 